\title{
Sztuczna inteligencja w wycenie instrumentów pochodnych. Studium przypadku dla opcji na indeks WIG20
}

\author{
Marta Kraszewska (D)
}

AGH Akademia Górniczo-Hutnicza, Wydział Elektrotechniki, Automatyki, Informatyki i Inżynierii Biomedycznej, Kraków

\begin{abstract}
Streszczenie: W pracy zaprezentowano możliwości zastosowania sztucznych sieci neuronowych do wyceny kontraktów opcyjnych na indeksy giełdowe. Omówiono wybrane prace, w których autorzy podejmowali próby wykorzystania sieci neuronowych do wyceny opcji na indeksy najważniejszych giełd na świecie. Przedstawiono analityczne metody wyceny opcji oraz zaproponowano model sieci neuronowej do wyceny kontraktów opcyjnych. Zaprezentowane eksperymenty dla opcji sprzedaży na indeks WIG20 Giełdy Papierów Wartościowych w Warszawie dla różnych okresów czasowych, w szczególności dla sytuacji, w których dochodzi do gwałtownych wahań kursów na giełdzie, zostały przygotowane z wykorzystaniem pakietu Statistica. Przedstawiono analizę wyników uzyskanych dla zaproponowanych modeli opartych na sztucznych sieciach neuronowych i znanego z matematyki finansowego modelu Mertona.
\end{abstract}

Słowa kluczowe: sztuczne sieci neuronowe, instrumenty pochodne, opcje, indeks WIG20, model Mertona

\section{ARTIFICIAL INTELLIGENCE IN THE VALUATION OF DERIVATIVES. CASE STUDY FOR OPTIONS ON THE WIG20 INDEX}

\begin{abstract}
The paper presents the possibilities of using artificial neural networks for the valuation of option contracts on stock index. Selected papers were discussed, in which the author attempted to use neural networks in option valuation of the most important stock exchanges in the world. Analytical methods of option valuation were presented and a neural network model for the valuation of option contracts was proposed. The presented experiments for the put option on the WIG20 index of the Warsaw Stock Exchange for various time periods, in particular for situations in which there are sudden fluctuations on the market, were prepared using the Statistica application. The paper presents an analysis of the results received for the proposed models using artificial neural networks and Merton model.
\end{abstract}

Keywords: artificial neural networks, derivatives, options, WIG20 index, Merton model

https://doi.org/10.7494/978-83-66727-47-2_7 


\section{Wprowadzenie}

Sztuczna inteligencja to umiejętność wykonywania przez komputer czynności, które zwyczajowo wymagają interwencji i inteligencji ludzkiej. Jej rozwój motywowany jest wzrostem ilości danych gromadzonych przez podmioty przy jednoczesnym spadku kosztów związanych z ich przechowywaniem i przetwarzaniem. Możliwość analizowania i w konsekwencji wyciągania wniosków ze zgromadzonych danych to w dzisiejszych czasach jedna z największych szans na uzyskanie przewagi konkurencyjnej na rynku.

Sztuczne sieci neuronowe znajdują obecnie zastosowanie w wielu dziedzinach gospodarki. Niewątpliwie wpływ na to mają ich podstawowe zalety, jakimi są: umiejętność samodzielnego „programowania się” sieci w trakcie procesu uczenia, zdolność do uogólniania posiadanej wiedzy oraz stosunkowo duża odporność na błędy pomiarowe. W jednej z prac R. Tadeusiewicza zaprezentowano przegląd ciekawych, aktualnie rozwijanych obszarów wykorzystania sieci neuronowych (Tadeusiewicz 2010).

Problemy ekonomiczne, ze względu na ich dużą złożoność, zaszumienie danych pomiarowych oraz występującą nieliniowość, są problemami, przy których rozwiązywaniu chętnie sięga się po sztuczne sieci neuronowe. Predykcja, klasyfikacja i kojarzenie danych, analiza danych, filtracja sygnałów czy optymalizacja, jako podstawowe klasy problemów ekonomicznych, z powodzeniem mogą być rozwiązywane przy zastosowaniu sztucznych sieci neuronowych.

Celem niniejszej pracy jest zaprezentowanie możliwości wykorzystania sztucznych sieci neuronowych do wyceny instrumentów pochodnych na indeks giełdowy na przykładzie kontraktów opcyjnych na indeks WIG20 na Giełdzie Papierów Wartościowych w Warszawie. Przeprowadzone eksperymenty zostały wykonane z wykorzystaniem oprogramowania Statistica. W szczególności celem badań było przeanalizowanie sytuacji, w których niespodziewanie dochodzi do znacznych wahań kursów giełdowych, co powoduje gwałtowną zmianę wartości indeksu WIG20. Dodatkowym elementem badań było porównanie efektywności działania znanych z literatury analitycznych metod wyceny opcji oraz zaproponowanych modeli neuronowych.

\section{Analityczne metody wyceny opcji}

Opcje (option), zwane również kontraktami opcyjnymi (option contracts), zaliczają się do instrumentów pochodnych (derywatów). Są terminowymi transakcjami warunkowymi, w których jedna ze stron nabywa prawo, a nie obowiązek, do kupna lub sprzedaży określonych instrumentów bazowych (np. indeksu, akcji, obligacji, waluty), po określonej cenie i w określonym czasie (Hull 1997a).

Wyróżniamy dwa podstawowe rodzaje opcji - opcje kupna (call option) i opcje sprzedaży (put option). Cena, po jakiej nabywca kontraktu ma prawo, ale nie obowią- 
zek, kupić lub sprzedać instrument bazowy (underlying asset), nazywana jest ceną zakupu, premią lub premią opcyjną (option premium). Nie jest ona zwracana nabywcy kontraktu nawet wówczas, gdy opcja nie zostanie wykonana. Kurs wykonania (realizacji) opcji (exercise price, strike price) to umowny kurs, po którym następuje rozliczenie kontraktu opcyjnego.

Wycena instrumentów pochodnych stanowi istotny problem matematyki finansowej. Dynamiczny rozwój rynków finansowych, któremu nieodłącznie towarzyszy rosnące zainteresowanie instrumentami pochodnymi wśród potencjalnych inwestorów, w tym również opcjami, spowodował, że ciągle podejmowane są próby przeprowadzania badań zarówno w zakresie teorii, jak i praktycznej konstrukcji metod wyceny (Hull 1997a, 1997b, Smithson i in. 2000, Pipień 2006). W szczególności wiele prac poświęconych zostało problemowi wyceny opcji (Garcia i Gençay 2000, Ait-Sahalia i Duarte 2003, Bondarenko 2003, Garcia i in. 2003, Ghysel i Tauchen 2003).

W ciągu ostatnich kilku dekad opracowano wiele modeli matematycznych, które stanowią pewne uproszczenie rzeczywistych warunków panujących na rynku finansowym. Dlatego też, wykorzystywane w analitycznych metodach wycen opcji, wzory określające wartość opcji należy traktować jako przybliżone i stosując je w praktyce, należy mieć na uwadze poczynione założenia upraszczające.

\subsection{Model wyceny opcji Blacka-Scholesa}

Istotnym punktem w historii rozwoju modeli do wyceny instrumentów pochodnych był rok 1973, kiedy to Fisher Black i Myron Scholes zaproponowali model wyceny opcji, który - po wprowadzeniu różnych modyfikacji - stosowany jest do dziś przez większość uczestników rynków kapitałowych (Black i Scholes 1973).

W modelu Blacka-Scholesa ceny europejskich opcji kupna i sprzedaży akcji spółek niewypłacających dywidendy definiowane są następująco:

$$
\begin{aligned}
& C_{B S}=S N\left(d_{1}\right)-X e^{-r T} N\left(d_{2}\right) \\
& P_{B S}=-S N\left(-d_{1}\right)+X e^{-r T} N\left(-d_{2}\right)
\end{aligned}
$$

gdzie:

$C_{B S}$ - cena (premia) europejskiej opcji kupna akcji spółek,

$P_{B S}$ - cena (premia) europejskiej opcji sprzedaży akcji spółek,

$S$ - cena instrumentu bazowego, na który wystawiona jest opcja,

$X$ - cena wykonania opcji,

$N$ - dystrybuanta standardowego rozkładu normalnego $N(0,1)$,

$r$ - wolna od ryzyka stopa procentowa,

$T$ - czas pozostający do wygaśnięcia opcji, 
oraz funkcje $d_{1}$ i $d_{2}$ wyrażone odpowiednio jako:

$$
\begin{aligned}
& d_{1}=\frac{\ln \left(\frac{S}{X}\right)+\left(r+\frac{\sigma^{2}}{2}\right) T}{\sigma \sqrt{T}} \\
& d_{2}=\frac{\ln \left(\frac{S}{X}\right)+\left(r-\frac{\sigma^{2}}{2}\right) T}{\sigma \sqrt{T}}=d_{1}-\sigma \sqrt{T}
\end{aligned}
$$

gdzie $\sigma$ - zmienność cen instrumentu bazowego.

Uogólniając, zarówno cena europejskiej opcji kupna, jak i sprzedaży akcji spółek jest funkcją:

$$
\begin{aligned}
C_{B S} & =f(S, X, r, T, \sigma) \\
P_{B S} & =f(S, X, r, T, \sigma)
\end{aligned}
$$

Teoria Blacka-Scholesa wpłynęła na rozpowszechnienie wykorzystania procesów stochastycznych do modelowania wielkości ekonomicznych m.in. w zagadnieniach zarządzania ryzykiem, konstrukcji optymalnych strategii inwestycyjnych czy wycenie instrumentów pochodnych (Hull 1997b, Neftci 2000, Jakubowski i in. 2003, Jajuga i Jajuga 2004, Musiela i Rutkowski 2005, Weron i Weron 2005, Brigo i Mercurio 2006, Mercurio 2009).

Teoretycznie rynkowe ceny opcji powinny być niemal idealnie równe wartościom wynikającym z modelu Blacka-Scholesa. Jednak nie zawsze tak jest ze względu na to, że model ten jest lepszym lub gorszym, ale jednak tylko przybliżeniem rzeczywistej sytuacji na rynku. Przykładowo rozkład prawdopodobieństwa ceny akcji w przyszłości nie ma postaci rozkładu logarytmiczno-normalnego.

Rezultaty teorii Blacka-Scholesa są poddawane dyskusji, ponieważ w praktyce cena opcji może być różna od teoretycznej wartości uzyskanej na podstawie modelu. Wynika to z faktu, że model Blacka-Scholesa opiera się na szeregu założeń, które niekoniecznie są potwierdzone przez obserwacje empiryczne. Ponadto rozważania teoretyczne nie uwzględniają tak oczywistego faktu jak zjawisko gwałtownych załamań kursów na giełdzie. Stworzenie opisu takiego zagadnienia jest aktualnie jednym z powodów ogromnego zainteresowania rynkiem kapitałowym. Przyczyną gwałtownych ruchów cen na rynkach kapitałowych, istotnie wpływających na wycenę opcji, są trudne do przewidzenia czynniki zewnętrzne. Przykładem jest atak terrorystyczny na World Trade Center z 11 września 2001 roku. W takiej sytuacji do teoretycznych wycen modeli należy podchodzić bardzo ostrożnie. Ostatecznie o cenie giełdowej instrumentu de- 
cyduje zainteresowanie wśród inwestorów, którzy przy wyznaczaniu ceny instrumentu mogą brać pod uwagę inne czynniki niż te uwzględnione w modelach teoretycznych.

Mimo wspomnianych zastrzeżeń do modelu wyceny opcji Blacka-Scholesa jest on powszechnie stosowany przez giełdy prowadzące obrót tymi instrumentami. Zmodyfikowany model Blacka-Scholesa jest również wykorzystywany do wyceny opcji na indeks WIG20 Giełdy Papierów Wartościowych w Warszawie.

\subsection{Model wyceny opcji Mertona}

Zaproponowany przez Blacka i Scholesa model wyceny instrumentów pochodnych został rozwinięty $\mathrm{w}$ kolejnych latach i stopniowo dokonywano redukcji początkowych ograniczeń tego modelu. Jeszcze w 1973 roku ukazała się praca Roberta C. Mertona, w której uogólnił wzór na cenę opcji, dopuszczając wypłatę dywidendy o stałej stopie (Merton 1973). Merton przyjął założenie, że dla nabywcy opcji kupna wartość akcji jest obniżona o bieżącą wartość wypłaconych do terminu wygaśnięcia dywidend oraz że koszt posiadania akcji jest zredukowany przez wypłacone dywidendy. Ponadto Merton rozszerzył swój model, obejmując nim wycenę europejskich opcji kupna i sprzedaży na indeksy giełdowe:

$$
\begin{aligned}
& C_{B S_{-} \text {index }}=S e^{-g T} N\left(d_{1}\right)-X e^{-r T} N\left(d_{2}\right) \\
& P_{B S \_ \text {_index }}=-S e^{-g T} N\left(-d_{1}\right)+X e^{-r T} N\left(-d_{2}\right)
\end{aligned}
$$

gdzie:

$C_{B S \_ \text {index }}$ - cena (premia) europejskiej opcji kupna na indeks giełdowy,

$P_{B S_{-} \text {index }}$ - cena (premia) europejskiej opcji sprzedaży na indeks giełdowy,

$g$ - wyrażona w stosunku rocznym średnia stopa dywidendy dla indeksu w okresie ważności kontraktu (pod uwagę brane są jedynie dywidendy, dla których dzień określenia praw do nich przypada w okresie ważności opcji),

oraz funkcje $d_{1}$ i $d_{2}$ wyrażone odpowiednio jako:

$$
\begin{aligned}
& d_{1}=\frac{\ln \left(\frac{S}{X}\right)+\left(r-g+\frac{\sigma^{2}}{2}\right) T}{\sigma \sqrt{T}} \\
& d_{2}=\frac{\ln \left(\frac{S}{X}\right)+\left(r-g-\frac{\sigma^{2}}{2}\right) T}{\sigma \sqrt{T}}=d_{1}-\sigma \sqrt{T}
\end{aligned}
$$


Podsumowując, można zapisać, że zarówno cena europejskiej opcji kupna, jak i sprzedaży na indeksy giełdowe jest funkcją:

$$
\begin{aligned}
& C_{B S_{-} \text {index }}=f(S, X, r, T, \sigma, g) \\
& P_{B S_{-} \text {index }}=f(S, X, r, T, \sigma, g)
\end{aligned}
$$

\section{Sztuczne sieci neuronowe $w$ wycenie instrumentów pochodnych}

Znanych jest co najmniej kilkadziesiąt prac, których autorzy podejmowali próby wykorzystania sieci neuronowych do wyceny instrumentów pochodnych. Obszerny przegląd literatury zawarty jest w pracy F. Chena i Ch. Sutcliffe'a (Chen i Sutcliffe 2011). W większości przedstawionych prac (łącznie 98 niezależnych analiz) wycena z wykorzystaniem modeli opartych na sieciach neuronowych była bliższa wartościom rynkowym aniżeli w przypadku zastosowania modelu matematycznego Blacka-Scholesa. Obszerny przegląd literatury można również znaleźć we wcześniejszych pracach autorki (Kraszewska 2010).

Pierwsze prace dotyczące wyceny kontraktów opcyjnych na indeksy giełdowe z wykorzystaniem modeli opartych na sieciach neuronowych pojawiły się w latach 1993-1994 (Hutchinson i in. 1994). Od tego momentu, według wiedzy autorki, opublikowano co najmniej kilkadziesiąt prac, w których poruszono problemy wyceny opcji na indeksy najważniejszych giełd na świecie (S\&P500, S\&P100, FTSE 100, DAX, OMX, KOSPI 200, SPI, CAC 40).

Opcje na indeks WIG20 Giełdy Papierów Wartościowych w Warszawie są szczególnymi papierami wartościowymi ze względu na fakt, iż indeks WIG20 - na który są one wystawione - w odróżnieniu od większości indeksów giełd zagranicznych jest indeksem cenowym. Rodzi to istotne konsekwencje, bowiem zachodzi konieczność rozważenia dodatkowego parametru wejściowego przy budowie modelu neuronowego, jakim jest dochód $z$ dywidendy. Indeksy dywidend obliczane są na podstawie dochodów z akcji z tytułu dywidend pieniężnych, które są wypłacane przez spółki wchodzące w skład indeksu WIG20. Innym utrudnieniem związanym z prawidłową wyceną opcji na indeks WIG20 może być niska płynność rynku.

Zastosowanie modeli neuronowych, które posłużą do wyceny kontraktów opcyjnych na indeks WIG20, może być interesującą alternatywną propozycją względem powszechnie stosowanych modeli matematyki finansowej, które w sytuacji zawirowań giełdowych nie zawsze dobrze radzą sobie z wyceną instrumentów pochodnych. Takie podejście może być ciekawą propozycją dla przedsiębiorstw i inwestorów bliżej zainteresowanych lokowaniem środków finansowych na rynku instrumentów pochodnych. 


\section{Sztuczna inteligencja a opcje na indeks WIG20 - studium przypadku}

Pierwowzorem sztucznej sieci neuronowej jest biologiczny układ nerwowy. Jest to złożona struktura, której głównymi elementami są komórki nerwowe (neurony) i połączenia między nimi. Mózg zawiera około 10 miliardów neuronów, które posiadają połączenia z innymi neuronami - tworzą one strukturę, która jest w stanie przysyłać i przetwarzać informacje. W celu odwzorowania modelu komórki nerwowej twórcy sieci neuronowych zdefiniowali uproszczony i przedstawiony w postaci matematycznej model sztucznego neuronu, który stanowi podstawowy element budowy sztucznej sieci neuronowej (Duch i in. 2000).

Możliwości pojedynczego neuronu (rys. 1) w zakresie przetwarzania informacji są stosunkowo niewielkie. W związku z tym najczęściej stosowane są połączone ze sobą grupy sztucznych neuronów, czyli sieci neuronowe pozwalające na wykonanie bardziej złożonych obliczeń.

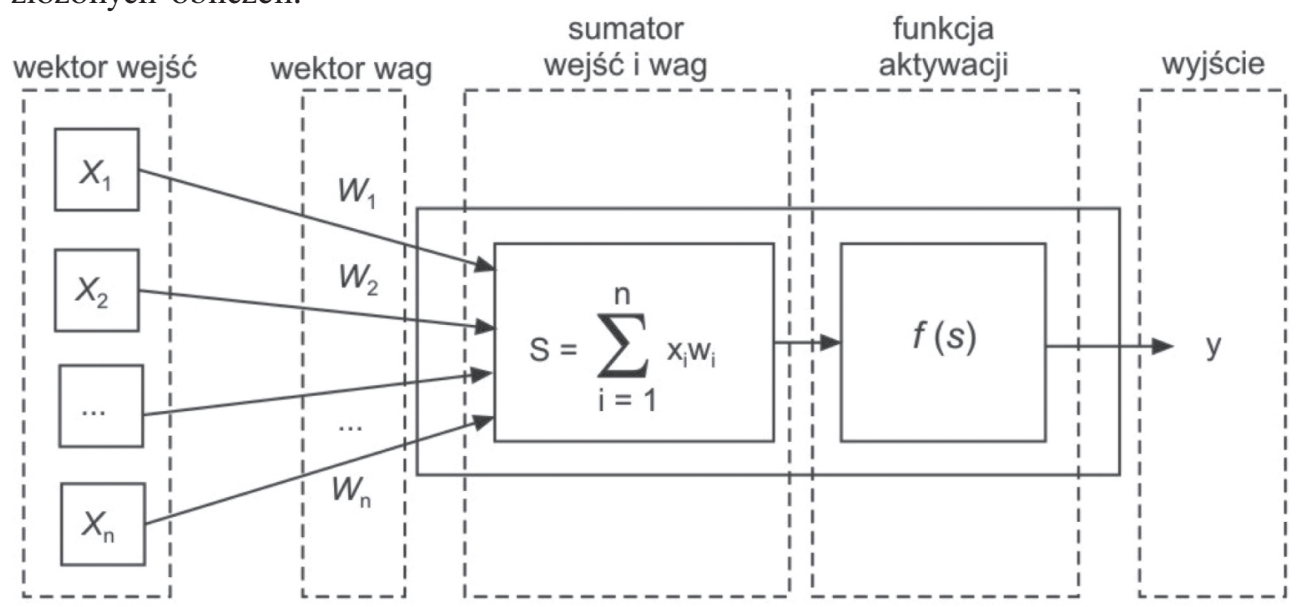

Rys. 1. Model sztucznego neuronu

W literaturze istnieje wiele definicji sieci neuronowych (Hecht-Nielsen 1990, Żurada 1992, Cichocki i Unbehauen 1993, Nigrin 1993, Havkin 1994, Żurada i in. 1996). Jak podaje R. Tadeusiewicz, sieć neuronowa jest bardzo uproszczonym modelem mózgu. Składa się ona z dużej liczby (od kilkuset do kilkudziesięciu tysięcy) elementów przetwarzających informację (Tadeusiewicz 1993). Elementy te nazywane są neuronami, chociaż w stosunku do rzeczywistych komórek nerwowych ich funkcje są bardzo uproszczone. Neurony są powiązane w sieć za pomocą połączeń o parametrach (wagach) modyfikowanych w trakcie procesu uczenia. Topologia połączeń oraz ich parametry stanowią program działania sieci, zaś sygnały pojawiające się na jej wyjściach, w odpowiedzi na określone sygnały wejściowe, są rozwiązaniami stawianych jej zadań (Tadeusiewicz 1993). 
Stosowaną formą organizacji sztucznej sieci neuronowej jest grupowanie neuronów w warstwy. Struktura sieci neuronowej składa się z warstw: wejściowej, ukrytych i wyjściowej (rys. 2).

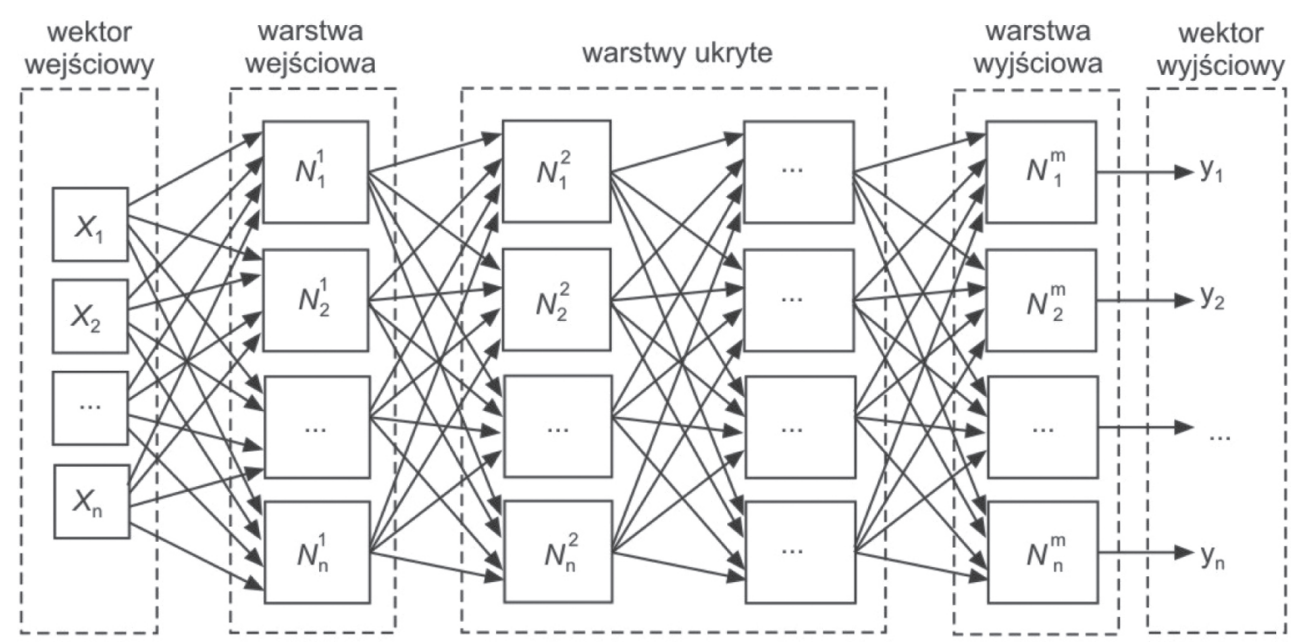

Rys. 2. Struktura sztucznej sieci neuronowej

\subsection{Zaproponowana budowa sieci neuronowej}

Jednym z najistotniejszych elementów konstrukcji modelu neuronowego jest wybór sieci. Dokonując wyboru typu sieci, należy uwzględnić te topologie sieci, które są przydatne do opisu zależności występujących pomiędzy zestawem danych wejściowych (opóźnionych wartości szeregu składowego) i danych wyjściowych (przyszła wartość tego szeregu).

W przeprowadzonych badaniach eksperymentalnych wykorzystano perceptrony wielowarstwowe MLP, które należą do dobrze poznanych i często wykorzystywanych architektur sieciowych. Do analizy doboru zmiennych wejściowych sieci neuronowej wykorzystano model matematyczny wyceny opcji, zwany modelem Mertona.

Założono, że sieć będzie miała 6 zmiennych wejściowych, 1 warstwę ukrytą o dowolnej liczbie neuronów oraz 1 wyjście (rys. 3). Parametrami wejściowymi sieci są:

$S$ - aktualna wartość instrumentu bazowego WIG20, na który wystawiona jest opcja,

$X$ - cena wykonania opcji,

$r$ - wolna od ryzyka stopa procentowa,

$T$ - czas pozostający do wygaśnięcia opcji,

$g$ - stopa dywidendy,

$\sigma$ - zmienność implikowana instrumentu bazowego WIG20. 


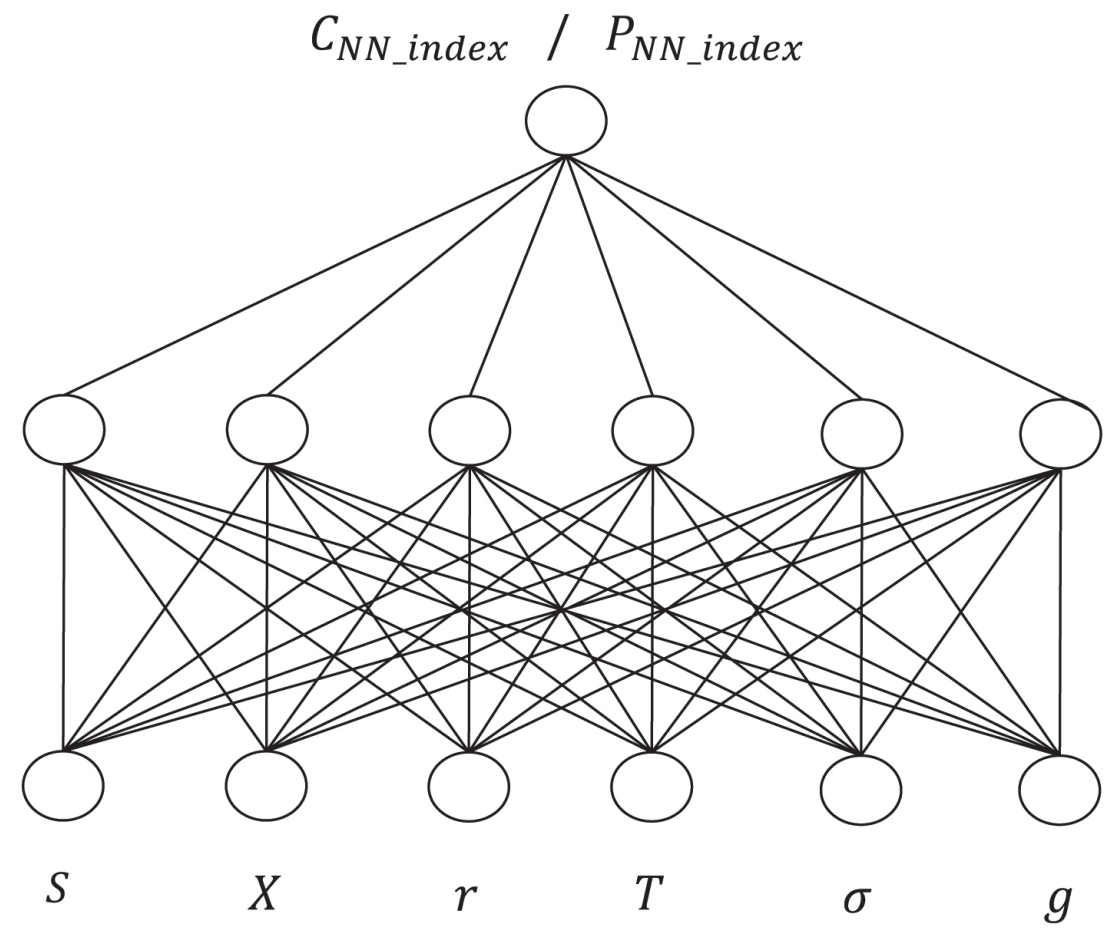

Rys. 3. Zaproponowana struktura sieci neuronowej

Wyjście sieci neuronowej reprezentuje wartość premii dla opcji kupna $C_{N N_{-} \text {index }}$ lub opcji sprzedaży $P_{N N_{-} i n d e x}$, w zależności od rozważanego modelu sieci neuronowej.

\subsection{Walidacja zaproponowanych modeli neuronowych}

W przeprowadzonych badaniach wykorzystano dane rzeczywiste reprezentujące notowania opcji na indeks WIG20 Giełdy Papierów Wartościowych w Warszawie z lat 2005-2010. Część danych została pobrana z ogólnie dostępnego archiwum notowań Giełdy Papierów Wartościowych. Pozostałe dane konieczne do zbudowania modeli sieci neuronowych zostały udostępnione bezpłatnie przez GPW. Następnie zastosowano podejście eksperymentalne w doborze rodzaju i struktury sieci neuronowej do wyceny opcji na indeks WIG20. Wykorzystano również sposoby uczenia sieci neuronowej przy użyciu opcji automatycznego poszukiwania sieci dostępnej w module Automatyczne Sieci Neuronowe pakietu Statistica. Badania przeprowadzono dla jednokierunkowych sieci wielowarstwowych MLP oraz dla sieci o radialnych funkcjach bazowych RBF. Do analizy porównawczej wykorzystano znane z literatury i powszechnie stosowane uniwersalne miary jakości prognoz. 
Miernikami oceny poprawności wszystkich zbudowanych modeli neuronowych są:

- graficzna interpretacja w postaci wykresu rozrzutu będącego graficzną interpretacją korelacji, wyrażającego zależność wartości zmiennej zależnej w odniesieniu do przewidywań modelu neuronowego;

- błąd średni ME na wyjściu modelu neuronowego prezentowany w zależności od czasu pozostającego do wygaśnięcia opcji T wyrażonego w dniach oraz w zależności od parametru S/X określającego stosunek aktualnej wartości instrumentu bazowego WIG20 S, na który wystawione są opcje do ceny wykonania opcji X;

- przyjęte miary błędów.

W trakcie przeprowadzonych badań został również wykorzystany model Mertona wyceny europejskich opcji kupna i sprzedaży na indeksy giełdowe. Posłużył on do analizy efektywności zaproponowanych modeli neuronowych. Wynika to z faktu, że WIG20 jest indeksem cenowym, co oznacza, że przy jego obliczaniu bierze się pod uwagę ceny zawartych w nim transakcji bez uwzględniania dochodów z akcji (dywidend, praw poboru). Dlatego też przy wycenie opcji na indeks WIG20 należy również uwzględnić dochód z dywidendy. Założenie to wpływa na wektor zmiennych wejściowych sieci neuronowej i z tego względu jednym z parametrów wejściowych jest stopa dywidendy.

Zaprezentowany sposób doboru sieci neuronowej w celu rozwiązania postawionego problemu został ograniczony do możliwości oferowanych przez pakiet Statistica. Interesującą alternatywną propozycją, obok zaproponowanej w pracy, mogłoby być również zastosowanie algorytmów automatycznego doboru struktury sieci neuronowej, na przykład z wykorzystaniem algorytmów genetycznych. Takie podejście, wykorzystujące algorytmy genetyczne do doboru zmiennych wejściowych, zostało zaproponowane między innymi w rozprawie doktorskiej (Domaradzki 2007) i jest dla autorki inspiracją do kontynuowania dalszych badań w zakresie wyceny instrumentów pochodnych z wykorzystaniem innych metod sztucznej inteligencji.

\subsection{Przeprowadzone eksperymenty}

Zaprezentowane badania zostały przeprowadzone dla okresu, w którym miał miejsce ogólnoświatowy kryzys gospodarczy. Począwszy od drugiej połowy 2007, w związku ze zmieniającą się ogólnoświatową sytuacją oraz rozpoczynającym się kryzysem sektora bankowego, nastąpiło odwrócenie trendu wzrostowego WIG20 na trend spadkowy. Rok 2008 był dla Giełdy Papierów Wartościowych w Warszawie najtrudniejszym rokiem w jej dotychczasowej historii. Dotkliwa bessa nie oszczędziła inwestorów na całym świecie. Spadek głównego indeksu warszawskiej giełdy w tym okresie był mniejszy niż innych giełd w regionie Europy Środkowo-Wschodniej, ale i tak finalnie WIG20 zanotował spadek o 48\%. Początek 2009 roku był kontynuacją dotkliwych 
spadków kryzysowego roku 2008. Jednak już w lutym nastąpiło odwrócenie trendu i powolny, ale systematyczny wzrost indeksów; w ciągu całego roku wszystkie indeksy warszawskiej giełdy zanotowały kilkudziesięcioprocentowe wzrosty. Na koniec roku WIG20 zyskał ponad 33\%. W latach 2008-2009 dzienne wahania wartości indeksu WIG20 były nawet dwukrotnie wyższe niż w okresie stabilnego wzrostu przypadającego na lata 2005-2007.

Celem badań było przenalizowanie szczególnych sytuacji na rynku, tj. momentów, w których nagle i niespodziewanie dochodzi do znacznych wahań kursów giełdowych, co miało miejsce szczególnie często w latach 2008-2009. Gwałtowna zmiana wartości indeksu WIG20 jednoznacznie wpływa na jego zmienność implikowaną. W związku $\mathrm{z}$ tym zbadano, jak w takich sytuacjach poradzi sobie model neuronowy i model Mertona.

Zbiór obserwacji został podzielony według schematu: 7070 - 1515 - 1515 na podzbiory: uczący, testowy i walidacyjny.

W wyniku uczenia sieci najniższą wartość współczynnika $I^{2}$ Theila równą 0,0044 uzyskano dla sieci MLP nr 2 z 8 neuronami w warstwie ukrytej oraz wykładniczą funkcją aktywacji dla neuronów ukrytych i wyjściowych (tab. 1).

\section{Tabela 1}

Miary błędów dla wybranych sieci neuronowych

\begin{tabular}{|c|c|c|c|c|c|c|}
\hline $\begin{array}{c}\text { Numer } \\
\text { sieci }\end{array}$ & Typ sieci & ME & MAE & RMSE & $R^{2}$ & $I^{2}$ Theila \\
\hline- & Model Mertona & 0,451 & 7,390 & 18,204 & 0,992 & 0,00596 \\
\hline 2 & MLP 6-8-1 & $-0,361$ & 9,231 & 15,583 & 0,994 & 0,00437 \\
\hline 12 & MLP 6-10-1 & $-0,582$ & 9,682 & 15,963 & 0,977 & 0,00518 \\
\hline 24 & MLP 6-12-1 & $-0,573$ & 9,340 & 15,594 & 0,978 & 0,00493 \\
\hline
\end{tabular}

Przeprowadzono szczegółową analizę poszczególnych serii opcji sprzedaży. Zauważono bowiem, że rozważając indywidualnie poszczególne wyceny z wykorzystaniem modelu Mertona, dla części z nich uzyskano wyniki znacznie odbiegające od wycen rzeczywistych (rys. 4). Pogłębiona analiza zbioru danych dowodzi, że wyceny uzyskane z modelu Mertona różnią się znacznie w dniach sesyjnych, w których zmienność implikowana różniła się od wartości średniej w całym okresie notowań danej opcji sprzedaży (rys. 5).

Wartość błędu ME (błąd BS) w modelu Mertona na poziomie 0,451 (rys. 6) wskazuje, że uzyskane prognozy osiągnięte dla całego analizowanego zbioru danych są przeszacowane. W przypadku wyceny uzyskanej z modelu opartego na sieci neuronowej (rys. 7) błąd na poziomie $-0,361$ (błąd $N N$ ) wskazuje na niedoszacowanie względem rzeczywistych wycen rynkowych dla całego analizowanego zbioru obserwacji. 


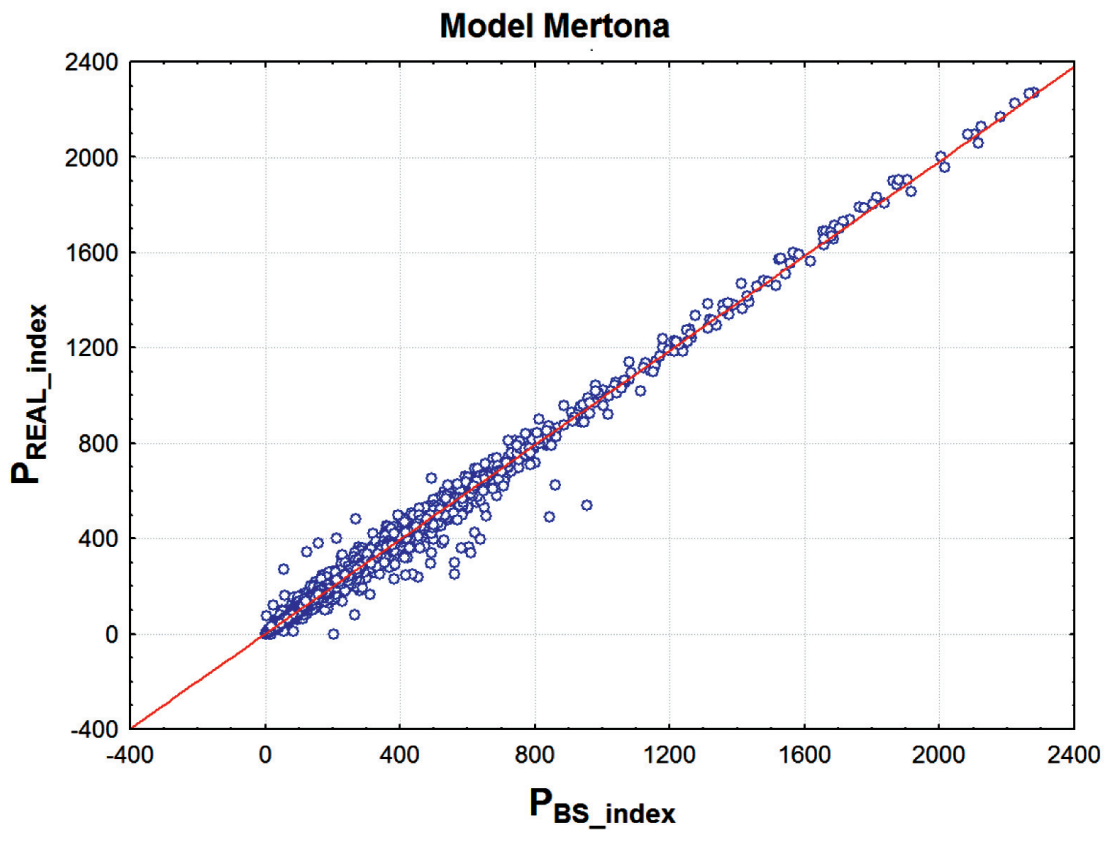

Rys. 4. Wykres rozrzutu dla modelu Mertona

\section{MLP 6-8-1 Próby: Uczenie, Test, Walidacja}

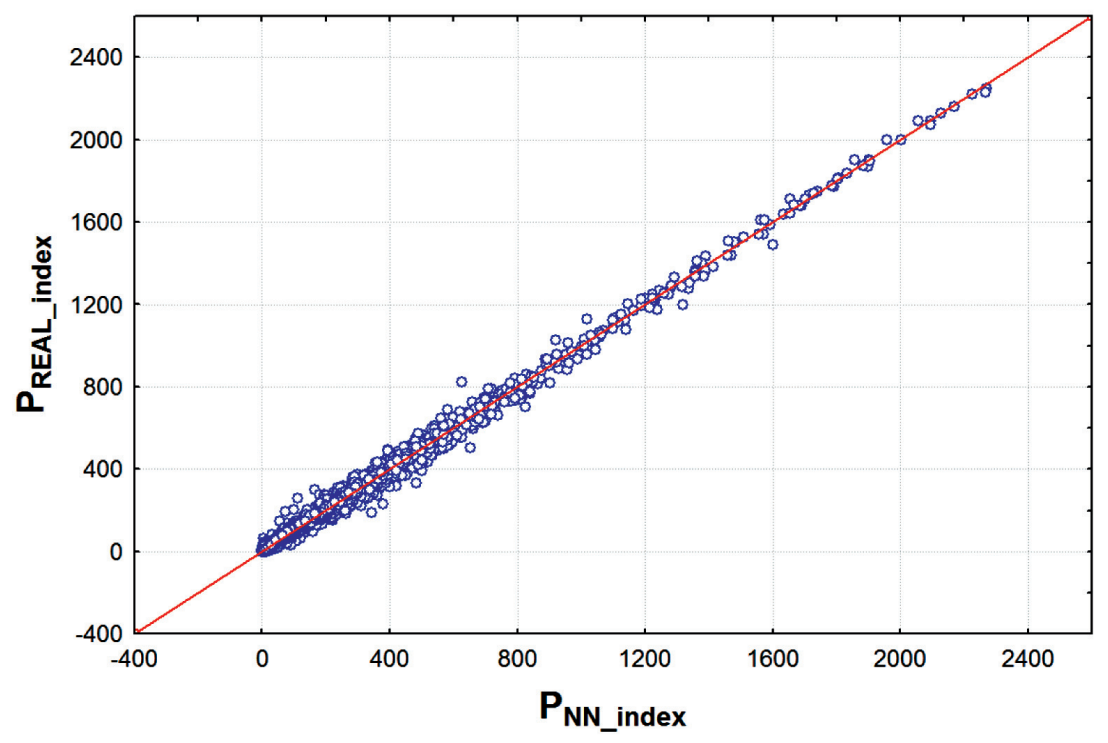

Rys. 5. Wykres rozrzutu dla modelu neuronowego nr 5 MLP 6-8-1 z 8 neuronami w warstwie ukrytej i wykładniczą funkcją aktywacji dla neuronów ukrytych i neuronów wyjściowych 


\section{Model Mertona}

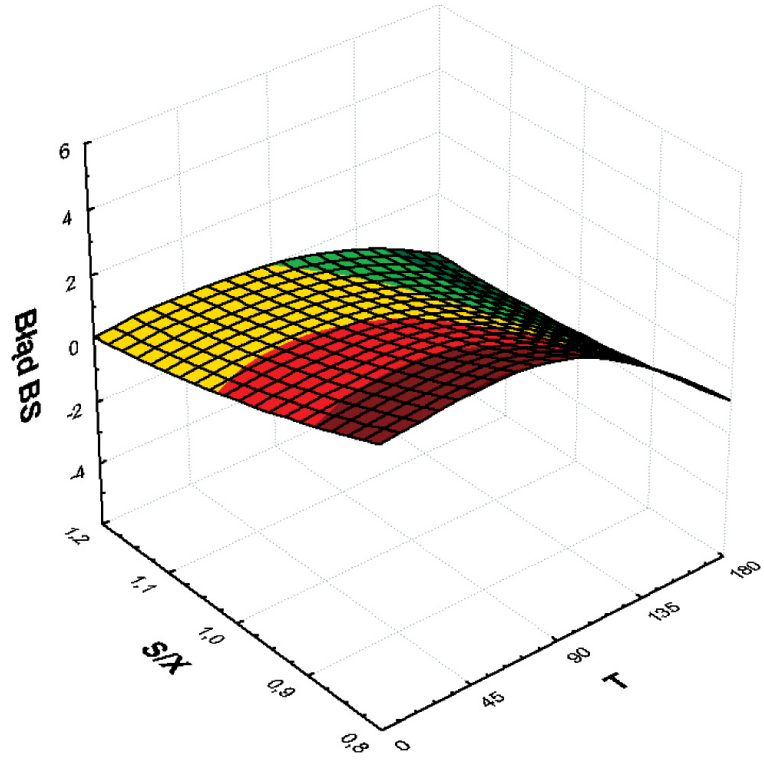

Rys. 6. Błąd średni ME dla modelu Mertona

\section{MLP 6-8-1}

\section{Próby: Uczenie, Test, Walidacja}

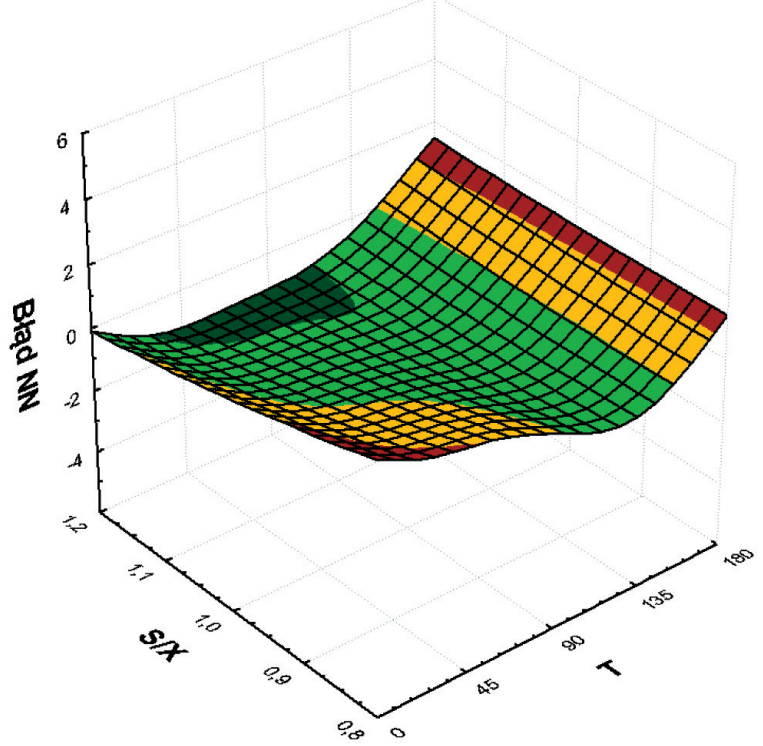

Rys. 7. Błąd średni ME dla modelu neuronowego nr 5 MLP 6-8-1 z 8 neuronami w warstwie ukrytej i wykładniczą funkcją aktywacji dla neuronów ukrytych i neuronów wyjściowych 
W kolejnym etapie badań przeanalizowano dynamiczną wycenę dla wybranych cen wykonania opcji sprzedaży do terminu jej wygaśnięcia. Dla rozpatrywanej opcji OW20O8310 w całym okresie zmienność implikowana wynosiła średnio 0,38. Na przełomie stycznia i lutego 2008 roku odnotowano znaczne wahania indeksu WIG20 (od 2\% spadków do 3\% wzrostów). W tych dniach również zmienność implikowana indeksu WIG20 była na poziomie dwukrotnie wyższym niż średnia wartość w całym okresie notowań opcji. W związku z tym wycena uzyskana na podstawie modelu Mertona odbiega od rzeczywistych wycen rynkowych (rys. 8).

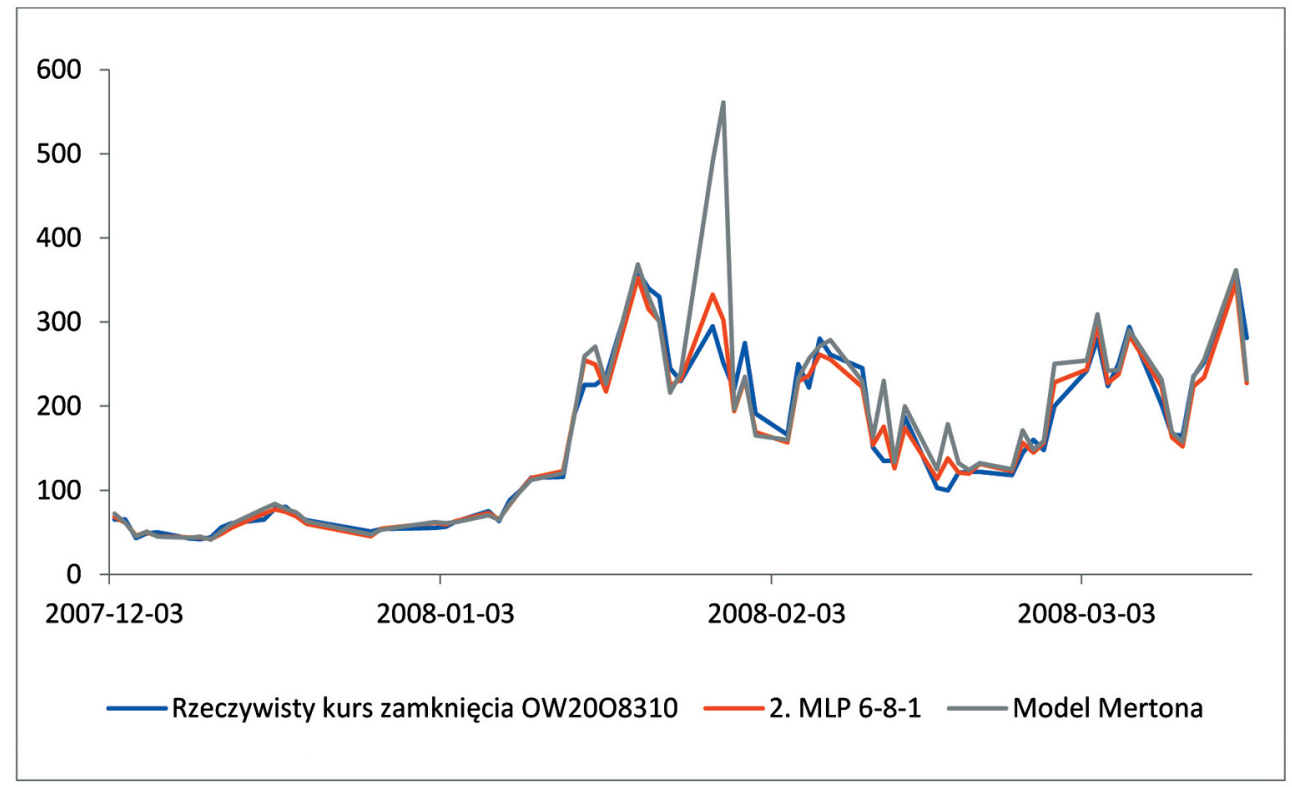

Rys. 8. Porównanie wyceny opcji OW20O8310 $\mathrm{z}$ terminem wygaśnięcia 20.03.2008 roku

Poniżej przedstawiono przykłady notowań dla opcji OW20O9230 z terminem wygaśnięcia 20.03.2009 roku (rys. 9) oraz OW20R9170 z terminem wygaśnięcia 19.06.2009 roku (rys. 10). Oba przypadki potwierdzają przypuszczenie, że w sytuacji gdy parametr zmienności implikowanej WIG20 nie utrzymuje się na podobnym poziomie, lecz ulega znacznym wahaniom, wyceny uzyskane za pomocą modelu Mertona różnią się od rzeczywistych wycen rynkowych.

Zaprezentowane przykłady wycen dla opcji sprzedaży wskazują, że w sytuacjach znacznych wahań na giełdzie z powodzeniem mogą być stosowane modele neuronowe jako narzędzie wspomagające wycenę tych instrumentów pochodnych. 


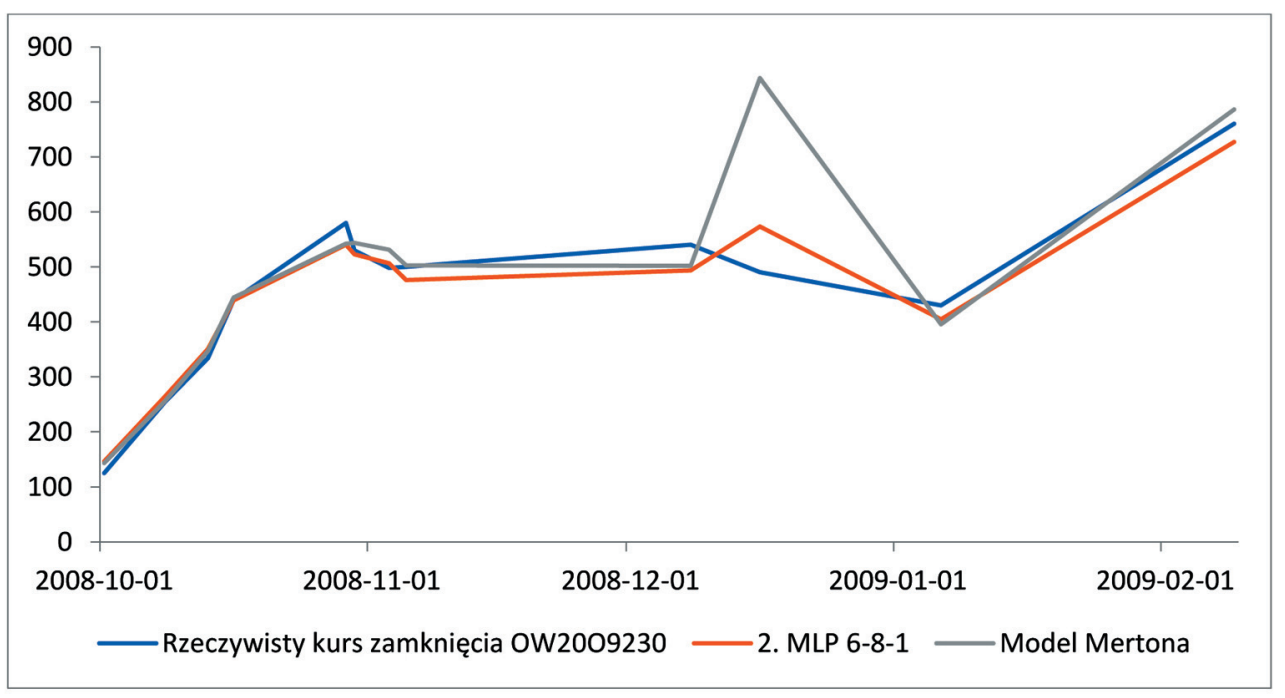

Rys. 9. Porównanie wyceny opcji OW20O9230

z terminem wygaśnięcia 20.03.2009 roku

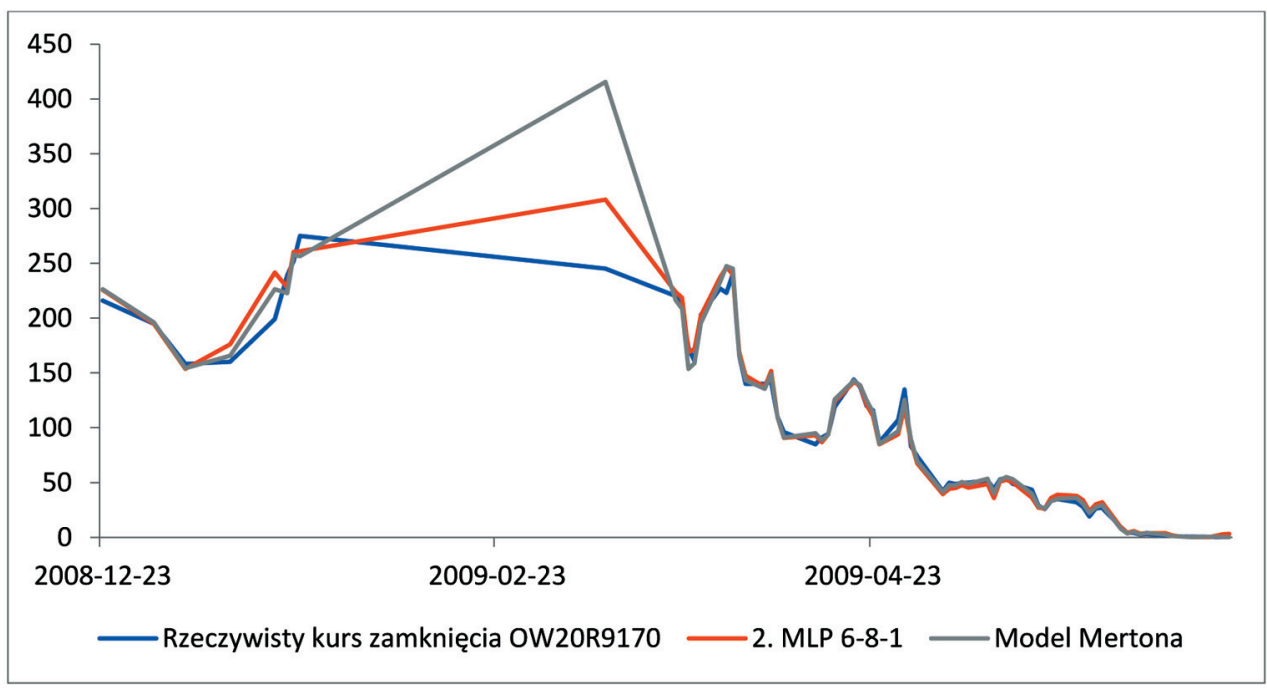

Rys. 10. Porównanie wyceny opcji OW20R9170

z terminem wygaśnięcia 19.06.2009 roku

\section{Podsumowanie}

Zaproponowanie modeli neuronowych, które mogą być wykorzystywane do wyceny opcji na indeks giełdowy, wydaje się interesującą alternatywną propozycją względem powszechnie stosowanych modeli matematyki finansowej. 
Zaprezentowane w pracy wyniki przeprowadzonych eksperymentów wykazały, że istnieje możliwość opracowania neuronowych modeli decyzyjnych, które mogą być przydatne w inwestowaniu w opcje na indeks WIG20 Giełdy Papierów Wartościowych w Warszawie. Zaproponowane modele oparte na sztucznych sieciach neuronowych dają lepsze wyniki niż inne znane analityczne metody wyceny opcji w sytuacji gwałtownych wahań kursów na giełdzie. Dla tak zdefiniowanych momentów czasowych, tj. w sytuacji gwałtownych zmian wartości indeksu WIG20, odbiegających od średniej wartości w okresie notowań opcji, model neuronowy wskazuje wartość premii opcyjnej zbliżoną do rzeczywistej wyceny rynkowej. Jest to istotna informacja dla inwestorów, ponieważ w takich sytuacjach teoretyczne wyceny opcji z wykorzystaniem znanych modeli matematycznych mogą różnić się od wycen rynkowych. Zaprezentowana w pracy dynamiczna wycena opcji sprzedaży w całym okresie ich notowań, w szczególności w sytuacji gwałtownych wahań kursów na giełdzie, pozwala wnioskować o trafności wycen $\mathrm{z}$ wykorzystaniem zaproponowanych modeli neuronowych.

Ciekawym kierunkiem kontynuowania prac badawczych mogłoby być przeprowadzenie eksperymentów dla danych rynkowych z okresu ogólnoświatowej pandemii COVID-19. W szczególności pierwsza połowa 2020 roku była okresem totalnej paniki, kiedy to 12 marca 2020 roku indeks największych spółek WIG20 stracił aż 14\%. Była to historycznie największa wyprzedaż akcji na GPW. W efekcie wiosennej paniki wśród inwestorów WIG20 zanotował spadek o około 40\%, co nasuwa porównanie z sytuacją z 2008 roku. Powtórzenie eksperymentów dla okresu z pandemii i skonfrontowanie ich z zaprezentowanymi w pracy wynikami uzyskanymi dla poprzedniego kryzysu jest kolejnym etapem prac badawczych autorki.

\section{Literatura}

Ait-Sahalia Y., Duarte J., 2003, Nonparametric Option Pricing Under Shape Restrictions, Journal of Econometrics, vol. 116, s. 9-47. https://doi.org/10.1016/S03044076(03)00102-7.

Black F., Scholes M., 1997, The pricing of options and corporate liabilities, Journal of Political Economy, vol. 81(3), s. 637-659. https://doi.org/10.1086/260062.

Bondarenko O., 2003, Estimation of Risk-Neutral Densities Using Positive Convolution Approximation, Journal of Econometrics, vol. 116, s. 85-112. https://doi.org/10.1016/ S0304-4076(03)00104-0.

Brigo D., Mercurio F., 2006, Interest Rate Models: Theory and Practice, $2^{\text {nd }}$ ed., Springer Finance, Heidelberg.

Chen F., Sutcliffe Ch., 2011, Pricing and Hedging Short Sterling Options Using Neural Networks, ICMA Centre Discussion Papers in Finance 2011, DP2011-18, University of Reading. https://doi.org/10.2139/ssrn.1929767. 
Cichocki A., Unbehauen R., 1993, Neural Networks for Optimization and Signal Processing, John Wiley \& Sons, New York.

Domaradzki R., 2007, Zastosowanie sieci neuronowych do generowania strategii decyzyjnych (inwestycyjnych) na przykładzie Giełdy Papierów Wartościowych, Akademia Górniczo-Hutnicza, Kraków [rozprawa doktorska].

Duch W., Korbicz J., Rutkowski L., Tadeusiewicz R., 2000, Biocybernetyka i inżynieria biomedyczna 2000. Tom 6. Sieci Neuronowe, Polska Akademia Nauk, Akademicka Oficyna Wydawnicza EXIT, Warszawa.

Garcia R., Gençay R., 2000, Pricing and Hedging Derivatives Securities with Neural Networks and a Homogeneity Hint, Journal of Econometrics, vol. 94, no. 1-2, s. 93-115. https://doi.org/10.1016/S0304-4076(99)00018-4.

Garcia R., Luger R., Renault E., 2003, Empirical Assessment of an Intertemporal Option Pricing Model with Latent Variables, Journal of Econometrics, vol. 116, no. 1-2, s. $49-83$.

Ghysel E., Tauchen G., 2003, Frontiers of Financial Econometrics and Financial Engineering, Journal of Econometrics, vol. 116, no. 1-2, s. 1-7. https://doi.org/10.1016/ S0304-4076(03)00101-5.

Haykin S., 1994, Neural Networks: A Comprehensive Foundation, Macmillan College Publishing Company, New York.

Hecht-Nielsen R., 1990, Neurocomputing, Addison Wesley Publishing Company, New York.

Hull J., 1997a, Kontrakty terminowe i opcje. Wprowadzenie, Wydawnictwo WIG-Press, Warszawa.

Hull J., 1997b, Options, Futures and Other Derivatives, Prentice Hall, New Jersey.

Hutchinson J.M., Lo A., Poggio T., 1994, A Nonparametric Approach to Pricing and Hedging Derivative Securities Via Learning Networks, Journal of Finance, vol. 49, no. 3, s. 851-889. https://doi.org/10.1111/j.1540-6261.1994.tb00081.x.

Jajuga K., Jajuga T., 2004, Inwestycje, instrumenty finansowe, ryzyko finansowe, inżynieria finansowa, Wydawnictwo Naukowe PWN, Warszawa.

Jakubowski J., Palczewski A., Rutkowski M., Stettner Ł., 2003, Matematyka finansowa: instrumenty pochodne, Wydawnictwa Naukowo-Techniczne, Warszawa.

Kraszewska M., 2010, Neural networks and the valuation of derivatives: some insights into the pricing of stocks index options, [w:] Sierpińska M., Szczepankowski P. (eds.), Contemporary trends in management and finance: theory and practice: 4th edition of the Economic international conference: Warsaw, 2010, November 18th-19th, Wizja Press \& IT, Warszawa, s. 177-188.

Mercurio F., 2009, Modelling Interest Rates: Advances in Derivatives Pricing, Risk Books, London. 
Merton R., 1973, Theory of Rational Option Pricing, Bell Journal of Economics and Management Science, vol. 4, s. 141-183. https://doi.org/10.2307/3003143.

Musiela M., Rutkowski M., 2005, Martingale Methods in Financial Modeling, Springer Verlag, Berlin.

Neftci S.N., 2000, An Introduction to the Mathematics of Financial Derivatives, $2^{\text {nd }}$ ed., Academic Press, Cambridge.

Nigrin A., 1993, Neural Network for Pattern Recognition, The MIT Press, Cambridge.

Pipień M., 2006, Wnioskowanie bayerowskie w ekonometrii finansowej, Wydawnictwo Akademii Ekonomicznej w Krakowie.

Smithson Ch.W., Smith C.W., Wilfrod D.S., 2000, Zarzadzanie ryzykiem finansowym, instrumenty pochodne, inżumieria finansowa i maksymalizacja wartości, Dom Wydawniczy ABC, Oficyna Ekonomiczna, Kraków.

Tadeusiewicz R., 1993, Sieci neuronowe, Akademicka Oficyna Wydawnicza RM, Warszawa.

Tadeusiewicz R., 2010, New Trends in Neurocybernetics, Computer Methods in Materials Science, vol. 10, no. 1, s. 1-7.

Weron A., Weron R., 2005, Inżynieria finansowa: wycena instrumentów pochodnych, symulacje komputerowe, statystyka rynku, Wydawnictwa Naukowo-Techniczne, Warszawa.

Żurada J.M., 1992, Introduction to Artificial Neural Systems, PWS Publishing Company, Boston.

Żurada J., Barski M., Jędruch W., 1996, Sztuczne sieci neuronowe: podstawy teorii i zastosowania, Wydawnictwo Naukowe PWN, Warszawa. 